Feyza Basar,

Assistant Professor of EU law at., Istanbul 29

Mayis University

\title{
IS FREEDOM OF EXPRESSION IN DANGER IN THE LIGHT OF THE CJEU DECISIONS ON THE CASES C-507-17 GOOGLE V. CNIL AND C-18/18 EVA GLAWISCHNIG- PIESCZEK V. FACEBOOK?
}

Last year in September and November, the Court of Justice of the European Union (CJEU) rendered two important judgements on landmark cases C-507/17 Google v. Commission nationale de L'informatique et des libertes (CNIL) (24 September 2019) and C-18/18 Eva Glawischnig-Piesczek v. Facebook Ireland Limited (G-P v. Facebook) (3 October 2019). At first sight, these cases do not directly related to those fundamental rights as they are more about personal, material and territorial limits on the scope of right to be forgotten (Google v. CNIL) or an injunction (G-P v. Facebook). However they, especially the second judgement, will have serious effect on freedom of expression and access to information. In Google v. CNIL, the CJEU ruled that French national data protection authority's order demanding that Google remove certain offending search results worldwide was impermissible. On the other hand, in G-P v. Facebook, the Court held that Article 15 of the EU's e-commerce directive does not prohibit EU Member States from ordering extremely broad injunctions against platforms like Facebook to take down offending material (and therefore allows it). The court held that these injunctions can cover a wide array of material-not just Facebook posts but also reposts and "equivalent" posts- and apply worldwide.

In this study, the limits to the freedom of expression and access to information shall be analysed under the case law of the ECtHR and CJEU with specific evaluation as the possible consequences of Google and Facebook judgements rendered by the CJEU.

Keywords: Freedom of expression, human rights, Google Case, Facebook Case, EU Law.

\section{Фейза Басар}

ЧИ С СВОБОДА ВИРАЖЕННЯ В НЕБЕЗПЕЦІ У СВІТЛІ РІШЕНЬ ССПЛ ПО СПРАВАХ С-507-17

\section{GOOGLE V. CNIL I C-18/18 EVA GLAWISCHNIG- PIESCZEK V. FACEBOOK?}

Минулого року у вересні та листопаді Суд Європейського Союзу (ЄС) виніс два важливі рішення щзодо знакових справ C-507/17 Google проти Національної комісії з питань інформатизації та свободи (CNIL) (24 вересня 2019 р.) ma C-18/18 Eva Glawischnig-Piesczek npomu Facebook Ireland Limited (GP npomu Facebook) (3 жовтня 2019 р.). На перший погляд, иі справи безпосередньо не пов'язані з особистими правами, оскільки вони більше стосуються особистих, матеріальних та територіальних обмежень сфери права (Goоgle проти CNIL) або судової заборони (G-P проти Facebook). Однак вони, особливо друге рішення, суттєво вплинуть на свободу вираження поглядів та доступ до інформації. У справі Google проти CNIL CСПЛ постановив, щзо наказ франиузького національного органу із захисту даних, який вимагає від Goоgle видалити певні результати пошуку в усьому світі, є недопустимим. 3 іншого боку, у справі GP проти Facebook Cуд постановив, щчо стаття 15 Директиви СС про електронну комерцію не забороняє державам-членам СС вказувати надзвичайно широкі судові заборони платформам, таким як Facebook, на видалення матеріалів. Суд постановив, шуо ичі судові заборони можуть охоплювати широкий спектр матеріалів - не лише дописи у Facebook, а й репости та «еквівалентні» дописи, і застосовуватимуться повсюдно.

У цьвому дослідженні обмеження свободи вираження поглядів та доступу до інформації потрібно проаналізувати відповідно до судової практики ССПЛ з конкретною оцінкою можливих наслідків рішень Gооgle ma Facebook від та ССПЛ.

Ключові слова: свобода слова, права людини, справа Google, cnpaва Facebook, право СC.

Introduction

Freedom of expression, protected by Article 1o of the European Convention on Human Rights (ECHR) and Article 11 of the Charter of Fundamental Rights (EUCFR) constitutes one of the essential foundations of a democratic society, one of the basic conditions for its progress and for the development of everybody. This right is a fundamental right which has been interpreted and developed in context by the case law of European Court of Human Rights (ECtHR) for a long time. Therefore it covers political expression, including political protests 
Basar F.

Is freedom of expression in danger in the light of the CJEU decisions on the cases C-507-17 google v. CNIL ...

and peaceful demonstrations. It protects popular and unpopular expressions, even shocking for others, subject to limitations stipulated under Article 10(2).

According to ECtHR case law, any restrictions on freedom of expression must be both 'necessary' and must pass a three-part test in each particular case. The second paragraph of Article 10 expressly states that any interference in freedom of expression by public authorities must be 'prescribed by law'. Having a legal basis for a restriction in national law is not sufficient to meet this important condition. Any law allowing such restrictions should have certain qualities (Akdeniz and Altıparmak, 2018, 18). ECtHR confirms that a norm cannot be regarded 'law' within the meaning of Article 10(2) unless it is formulated with sufficient precision to enable citizens to regulate their own conduct. ${ }^{1}$ Therefore, foreseeability and accessibility of the norm is very important for being regarded as law and it depends to a considerable degree to the content of the norm in question, the field it is designed to cover and to whom it is addressed. ${ }^{2}$

The notion of foreseeability applies not only to the pattern how individuals must regulate their conduct but also to the formalities, conditions, restrictions or penalties that can be applied to such conduct if it is found to be against national law. ${ }^{3}$ Even if the norm is considered to be law in terms of the Convention, the interference is still has to be based on one of the legal grounds stated in Article 10/2, i.e., national security, public safety, territorial integrity, prevention of disorder or crime, protection of health and morals, or protection of the reputation or rights of others (principle of legitimacy). According to the case law of the ECtHR, any restriction must be 'necessary in a democratic society' 4 and State interference must respond to a 'pressing social need'5 (principle of necessity). Lastly, the measures applied by the State and the restrictions prescribed by law must also be 'proportionate to the legitimate aim pursued' (principle of proportionality). ${ }^{6}$

All the Member States of the EU are party to the ECHR and have integrated it into their national systems. The Convention is thus part of the internal legal system and is binding on the national courts and all public institutions, including data protection authorities. Sometimes personal fundamental rights, such as protection of reputation or privacy, and freedom of expression may be in conflict or seem to be restricting each other. In practice, boundaries of personal rights will often vary from case to case, and thus will be left to the national courts of the State parties.

Indeed, the overall scheme regulated by the Convention is that the initial and primary responsibility for the protection of rights laid down in it lies with the contracting States. Although each individual State has a margin of appreciation, this applies differently and the degree of discretion allowed to the states varies according to the context. A state has considerable discretion in cases of public emergency arising under Article 15 of ECHR, or where there is little common ground between the contracting parties, while the discretion is reduced almost to vanishing point in certain areas, such as the protection of freedom of expression. These explanations are also relevant for the EU Member States and the CJEU has a significant role to provide the necessary guidance to them.

The first case under scrutiny in this study is Google Inc. v. CNIL ${ }^{7}$ which concerns the interpretation of Regulation (EU) 2016/679 (GDPR) on the protection of natural persons with regard to the processing of personal data and on the free movement of such data, and repealing Directive 95/46/EC with regard to the obligations of search engine operators. It is about the right of individuals to request, under certain conditions, that the search engine operator cease to include their personal information, in search results even when it is about a legally posted content. The judgement was delivered just a few days before the judgement against Facebook and the Advocate General of both cases is the same. In Google v. CNIL, the CJEU explicitly placed restrictions on the territorial scope of the individual's right to de-reference and ruled that there was no obligation under EU law for Google to globally exercise the right to be forgotten.

\footnotetext{
${ }^{1}$ See for example, Lindon, Otchakovsky-Laurens and July v. France [BD], No. 21279/02 and 36448/02, 22 October 2007, para. 41.

${ }^{2}$ See for example, Groppera Radio AG and Others v. Switzerland, No. 28.03.1990, 28 March 1990, para.68.

${ }^{3}$ See for example, Kafkaris v. Cyprus [BD], No.21906/04, 12 February 2008, para.140.

${ }^{4}$ See for example, Sunday Times v. United Kingdom (No.2), Series A No. 217, 26 November 1991; Okçuoğlu v. Turkey, No. 24246/94, 8 July 1999, para.50.

${ }^{5}$ See for example, Sürek v. Turkey (No.1), No. 26682/95, 8 July 1999, para.43.

${ }^{6}$ See for example, Bladet Tromso and Stensaas v. Norway [BD], No.21980/93, 20 May 1999.

${ }^{7}$ Case C-507/17, Google LLC v. Commission nationale de l'informatique et des libertes (CNIL), judgement of 24 September 2019 , EUR-Lex CELEX No. 62017CJ0507.
} 
The second case G-P v. Facebook ${ }^{8}$ is about an Austrian politician who requested Facebook to remove globally the content which she thought defamatory or harmful for her reputation. Unlike Google v. CNIL, the CJEU neither developed questions that need to be considered nor any explicit statement as to how to strike a balance between the right to privacy, including protection of reputation, and the freedom of expression. Instead, the Court imposed additional obligations on certain service providers, relating to the protection of users against offensive and defamatory content on social networks. The most striking part of the judgment is that the obligation to delete such content can be extended to cases where the content is further shared on the social network, even globally, and when the form is slightly modified, but the content almost remains the same.

In this study both cases will be examined from the fundamental rights perspective and the impact of the CJEU decisions on the freedom of expression will be evaluated.

\section{Relationship between the CJEU and the ECtHR}

The human rights policy of the EU has influence on two main fields. First of all, it affects all community actions and national actions/legislation which implement community law. Secondly, it affects the external relations of the EU by addressing human rights concerns in its dealing with the states which are not yet members of the EU. In the early years of the EU, the CJEU recognised human rights as a fundamental aspect of the community law, but it lacked a coherent policy. Whilst the CJEU ruled that the content of human rights protection derived from the constitutional traditions of the Member States ${ }^{9}$, and later to international agreements to which the states are party ${ }^{10}$, it did not refer directly to the provisions of the ECHR or the decisions of the ECtHR (Defeis, 2001: 302).

With the entry into force of the Amsterdam Treaty in 1999, the human rights standards laid down in the ECHR were incorporated into the EU law. In this respect Article 6(2) of the Amsterdam Treaty states that "the Union shall respect fundamental rights, as guaranteed by the European Convention for the Protection of Human Rights and Fundamental Freedoms." Thus, it became clear that the CJEU had a task to apply these human rights standards in relation to the acts of the EU Institutions and to the actions of the Member States implementing EU law.

The ECHR and the case law of the ECtHR have always been a source of inspiration for the CJEU ever since it started to develop its case law on human rights protection, even before the Amsterdam Treaty and it is mutual. In its earlier decisions, the ECtHR held that as long as the protection of fundamental rights in the EU is presumptively equivalent to that of the ECHR, the acts of the Member States which simply implement EU measures at the domestic level will not be reviewed by the ECtHR (Lavranos, 2008: 217). On the other hand in Bosphorus case, the ECtHR decided that the presumption of equivalence between the EU system for the protection of fundamental rights and the ECHR "can be rebutted if, in the circumstances of a particular case, it is considered that the protection of Convention rights was manifestly deficient." 11

The ECHR as an instrument of international law does not directly bind the EU, as the EU is not a party to this Convention as itself. However, since the entry into force of the Lisbon Treaty, the structure and scope of human rights protection on the level of the EU has dramatically changed. Especially, EU Charter of Fundamental Rights has strengthened the relationship between the EU legal system and that of the Convention. With reformulated Article 6 of the Lisbon Treaty, the Convention has gained binding effect within the EU legal system and accession of the EU to the ECHR is mandated.

Article 52(3) of the Charter provides that in so far as this Charter contains rights which correspond to rights guaranteed by the ECHR, the meaning and scope of those rights shall be the same as those laid down by the ECHR. According to the explanations of this provision, the level of protection afforded by the Charter may never be lower than that guaranteed by the ECHR. ${ }^{12}$ However, the EU law may provide more extensive protection. Freedom of expression is among the corresponding rights listed in the explanations. The relevance of the explanations for the interpretation of the Charter is underlined by the Article 6 (1) EU and Article 52(7) of the Charter. As the ECHR is now accepted as part of the EU law, this has to cover the interpretations given by the ECtHR to these provisions with regard to the corresponding fundamental rights, as well (Timmermans, 2014).

\footnotetext{
${ }^{8}$ Case C-18/18, Eva Glawishnig-Piesczek v. Facebook Ireland Limited, judgement of 3 October 2019.

${ }^{9}$ Case 29/69, Stauder v. Ulm Sozialamt, 1969 E.C.R. 419, 427 [1970] 10 C.M.L.R. 112, 1970.

${ }^{10}$ Case 4/73, Nold, Kohlen-und BaustoffsgroBhandlund v. Commission, 1974 E.C.R 491, [1974] 2 C.M.L.R. 338 [1974].

${ }^{11}$ Bosphorus Airways v. Ireland, No. 12323/1, 6 December 2012.

12 Notices from European Union Institutions and Bodies, Charter of Fundamental Rights of the European Union, OJ 2007, vol.50, C 303, p. 33.
} 
Triggered by the Charter gaining binding effect, the CJEU has delivered a series of remarkable decisions on freedom of expression ${ }^{13}$, human dignity, social rights, sexual orientation, non-discrimination on the basis of gender and political entitlements. Pending the conclusion of the process of EU accession to the ECHR, which was initially ruled out by the CJEU and then made possible by the amended Article 6 of the Lisbon Treaty both Courts have been trying to avoid conflicting decisions on the scope of fundamental rights (Cheburini, 2015: 1376). Accession of the EU to the ECHR will definitely change the relations between the CJEU and ECtHR, the latter officially becoming subject to the jurisdiction of the former but how it will take effect remains to be seen.

\section{Regulating the Freedom of Expression and On-line/Digital Platforms}

Recently, Europe has been experiencing an intense dilemma in protecting the free speech and regulating online platforms, including privacy. On a global scale, there is a basic distinction between two models in regulation: The first approach, currently prevailing in the US, supports the narrowest possible restrictions to the freedom of expression of individuals and media, "justifiable only when an imminent threat of violence arising from the speech in question can be foreseen and when there are no other reasonable means to prevent such violence" (Topidi, 2019: 3). Second approach has a tendency to penalise the speech, which might promote hatred. The European system is oriented more towards the balancing between private and public interests while ensuring that equality and dignity are maintained for all yet within a context where democratic principles are upheld (Tulkens, $2012: 1$ ). ${ }^{14}$ With the rise of populist and far-right political parties in Europe such concerns have become more pressing.

Freedom of expression is an essential principle characterising a democratic society, as the ECtHR stated in Handyside v. the UK, "freedom of expression constitutes one of the essential foundations of such a society, one of the basic conditions for its progress and for the development of every man". ${ }^{15}$ In this respect it has three dimensions: a speaker's right to express himself/herself, a listener's right to be protected from harmful expressions and a thirdparty's right not to allow harmful expressions in the public sphere (McGonagle, 2009:9). It is a fundamental right necessary for the individual's self-development, which is only possible when people can exchange competing ideas and beliefs and inevitable for shaping public opinion on all types of issues occupying the public sphere. (Barendt, 2005:13). As the ECtHR repeated in its case law several times, it is the State's responsibility and duty to create such an environment for participation of all those wishing to be part of the public debate. ${ }^{16}$

The media holds significant role in furthering public debate in a democratic society. In Castells v. Spain, the ECtHR stated that it is incumbent on the media to impart information and ideas on political questions and on other matters of political interest ${ }^{17}$, without suffering under the criminal law restricting the right of the public to be informed. The value of media pluralism represents the guarantee for public debate, which involves disagreement and confrontation (Topidi, 2019: 5).

The media serves as an important platform for public dialogue and with its role enhanced by digital technologies; it has become essential to consider how freedom of expression may be reconciled with the regulation of online/ditigal platforms in this area of public and private life. In one of its decisions ECtHR, recognised that "[ $\mathrm{t}]$ he internet has become one of the principal means for individuals to exercise their right to freedom of expression today: it offers essential tools for participation in activities and debates relating to questions of politics or public interest." 18

However, it is getting increasingly unclear where the line between the legitimate defence for the freedom of expression should be drawn as opposed to its misuse. For example, Germany has recently implemented "Enforcement on Social Networks Act"19, which requires social networks, such as Facebook, Twitter, Snapchat or Youtube, to remove specific kinds of content within 24 hours or otherwise face fines that could be as high as 50.000.000 EUR. Consequently, it is important to find the right balance between competing interests in this field. It

\footnotetext{
${ }^{13}$ See for example, Case C-112/00, Schmidberger Internationale Transporte and Planzüge v. Austria [2003] ECR I-5659 (recognising the right to freedom of expression as a justification for the restriction of the freedom of movement); Case 380/05 Centro Europa 7 Srl v. Ministero delle Comunicazioni e Autorita per le Granzie nelle Comunicazioni et al, [2008] ECR I-349 (declaring incompatible with EU law a provision of the Italian media law which did not ensure pluralism in the broadcasting system).

${ }^{14}$ In data protection law, we see that the US has tendency to favour national/public interests over private interests whereas the EU favours individuals' rights and interests.

${ }^{15}$ Handyside v. the United Kingdom, No. 5493/72, 7 December 1976, para.49.

${ }^{16}$ Dink v. Turkey, No.2668/07, 6102/08, 30079/08, 7072/09 and 7124/09, 14 September 2010, para.137.

${ }^{17}$ Castells v. Spain, No.11798/85, 23 April 2012, para.43.

${ }^{18}$ Ahmet Yildirim v. Turkey, No.3111/10, 18 December 2012, para.54.

${ }^{19}$ Gesetz zur Verbesserung der Rechtsdurchsetzung in sozialen Netzwerken, publication date: 07.09.2017.
} 
is very clear in the outcome of Google Spain and Google Case ${ }^{20}$ whereas the Court effectively read Articles 7 and 8 EUCFR into the Data Protection Directive, which had direct implications for private actors, not only for Google but also for other search engines who have drawn up procedures for weighing up the fundamental right to privacy (specifically right to be forgotten) themselves, so as to avoid further legal actions (Frantziou, 2019: 49).

Although traditional conceptions of constitutional theory have generally associated the application of fundamental right with state obligations, now it is established that certain fundamental rights have horizontal effect. The principle of horizontality or horizontal effect of fundamental rights indicates the application of these rights to disputes between private parties, rather than to disputes between individuals and state or other public law entities (Frantziou, 2019:1). In other words, private parties, such as business enterprises, are also responsible to respect human rights. However, private entities should not apply censorship measures and they have no obligation to monitor the information which they transmit or store, nor a general obligation actively to seek facts or circumstances indicating illegal activity as is put in Art.15 of the E-commerce Directive ${ }^{21}$ of the EU.

Indeed, in his June 2006 Report to Human Rights Committee, the Special Rapporteur on Freedom of Expression requested that States should abstain from delegating their duty to the private sector to determine content illegality of expression. He also stated that notice and take-down measures run the risk of over-broad regulation in this field. ${ }^{22}$ Again the E-Commerce Directive expressly prohibits Member States from imposing liability on intermediaries where these do not have actual knowledge of the illegal activity/information and upon obtaining that knowledge act expeditiously to remove access to the disputed content. Despite this, the on-going struggle to reconcile data privacy concerns with protection of human rights is clearly illustrated in the following two CJEU cases.

\section{and Injunction \\ 3. The CJEU Judgements about Personal, Material and Territorial Scope of Right to be Forgotten}

\subsection{Google v. CNIL Case $\mathrm{Ca}^{23}$}

The events leading to this case began on May 21, 2015, when the President of the Commission nationale de l'informatique et des libertés (CNIL), the French Data Protection Authority, served a formal notice on Google that, when grating a request from a natural person for links to web pages to be removed from the list of results displayed following a search conducted on the basis of that person's name, it must apply that removal to all its search engine's domain name extensions. Google refused to comply with that formal notice, confining itself to removing the links in question from only the results displayed following searches conducted from the domain names corresponding to the versions of its search engine in the Member States. CNIL also regarded as insufficient Google's further 'geo-blocking' proposal, whereby internet users would be prevented from accessing the results at issue from an IP address deemed to be located in the State of residence of a data subject after conducting a search on the basis of that data subject's name, no matter which version of the search engine they used.

By an adjudication of 10 March 2016, the CNIL after finding that Google had failed to comply with that formal notice within the prescribed time period imposed a penalty on that company of EUR 100.000. Google appealed to the Conseil d'Etat (Council of State, France), for an annulment of CNIL's adjudication. In the appeal process Google argued that the right to de-referencing (recognised by the CJEU in Google Spain and Google $\left.{ }^{24}\right)^{25}$ does not necessarily require that the links at issue are to be removed, without geographical limitation, from all its search engine's domain names. In addition, by adopting such interpretation, the CNIL disregarded the principles of courtesy and non-interference recognised by public international law and disproportionately infringed the freedom of expression, information, communication and the press guaranteed, in particular, by Article 11 of the Charter.

\footnotetext{
${ }^{20}$ Case C-131/12, Google Spain and Google v. AEPD and Mario Costeja Gonzalez, judgement of 13 May 2014, EU:C:2014:317.

${ }^{21}$ Directive 2000/31/EC of the European Parliament and of the Council of 8 June 2000 on certain legal aspects of information society services, in particular electronic commerce, in the Internal Market. OJ L 178, 17.7.2000.

${ }^{22}$ Report of the Special Rapporteur on Freedom Expression, 11 May 2016, A/HRC/32/38, paras.44-48.

${ }^{23}$ Case C-507/17, Google LLC v. Commission nationale de l'informatique et des libertes (CNIL), judgement of 24 September 2019 , EUR-Lex CELEX No. 62017CJ0507.

${ }^{24}$ Case C-131/12, Google Spain and Google v. AEPD and Mario Costeja Gonzalez, judgement of 13 May 2014, EU:C:2014:317.

${ }^{25}$ There was no provision regulating specifically "right to be forgotten in the Data Protection Directive 95/46/EC. Therefore, in Google Spain and Google Case the Court established a 'right to be forgotten' in that, on certain conditions, a person may have internet links de-referenced by the operator of the search engine. Now, the right to be forgotten regulated by Article 17 of the General Data Protection Regulation (EU) No 2016/679.
} 
As a result, the Conseil stayed the proceedings and asked the following questions to the CJEU for a preliminary ruling, basically, whether EU data protection law on de-referencing should be interpreted to mean that a search engine operator is required to remove links: (1) on all versions of its search engine (worldwide) or (2) only on the versions corresponding to all Member States (within the EU), or (3) only on the version corresponding to the Member State of residence of the person requesting de-referencing.

In its Opinion Advocate General (AG) Szpunar stated that "if world-wide de-referencing were admitted, the EU authorities would not be in a position to define and determine a right to receive information, still less to strike a balance between that right and the other fundamental rights to data protection and to private life, a fortiori because such a public interest in having access to information will necessarily vary, depending on its geographic location, from one third State to another"' Opinion para.60). He also added that there would be then a danger that the EU would prevent individuals in third countries from having access to information. If an authority within the EU could order de-referencing on a world-wide scale, an inevitable signal would be sent to third countries, which could also order de-referencing under their own laws. Hence, there would be a "genuine risk of a race to bottom, to the detriment of freedom of expression, on a European and world-wide scale" (Opinion para.61). Similarly, in its Opinion in Google Spain and Google, AG Jaaskinen considered that "the fundamental right to information merits particular protection in EU law, especially in view of the ever-growing tendency of authoritarian regimes elsewhere to limit access to the internet or to censure content made accessible by it." However, AG Szpunar also stated that he could not exclude the possibility that there may be situations in which the interests of the EU requires the application of the provisions of Directive 95/46 (Data Protection Directive) ${ }^{26}$ beyond the territory of the EU, but not in the present case.

Taking the side of Google and in parallel with the Opinion of Advocate General Szpunar, the Court held that search engine operators are not required under EU law to remove links on all the version of its search engine. In order to support its decision, the Court explained that the texts of the Data Protection Directive or GDPR (General Data Protection Regulation) ${ }^{27}$ do not indicate that EU legislature has chosen to confer a scope which would go beyond the territory of the Member States or has intended to impose on a search engine operator a dereferencing obligation on non-EU national versions of search engines.

In its ruling the Court emphasised the main aim to provide a high level of protection of personal data throughout the EU. Accordingly, it held that search engine operators are required to remove all the links on all the versions in the EU regardless of where the request to de-reference originates in the EU. It also held that search engine operators are required to supplement the de-referencing through measures that would prevent or seriously discourage an internet user located in the EU to gain access to de-referenced links when using a search engine version outside the EU.

From the fundamental rights perspective, the key part of the judgement is para. 72 in which the Court revealed an effort to establish the lawfulness of global de-referencing as a general principle. In this respect, the Court held that the EU law does not currently require that the de-referencing granted concern all versions of the search engine in question (global application), it does not prohibit it, either. Accordingly, a supervisory or judicial authority remains competent to balance the conflicting rights of personal data protection against the right to freedom of information under the national standards of protection of fundamental rights to order the operator of that search engine to carry out a de-referencing concerning all versions of that search engine. In other words, the Court leaves the door open for the possibility of global de-referencing as determined by a national data protection authority or a national court in the EU.

\subsection{Eva Glawisching-Piesczek v. Facebook Ireland Limited (G-P v. Facebook) Case ${ }^{28}$}

In April 2016, a Facebook user posted on his personal page an article entitled "Greens: Minimum income for refugees stay" from an Austrian magazine. The post generated a 'thumbnail' containing the title and a brief summary of the article, as well as a photograph of Ms. Eva Glawishnig-Piesczek, who is a member of the Nationalrat (National Council of Austria), chair of the parliamentary party 'die Grünen' (the Greens) and federal spokesperson for that party. That user also published, in connection with that article, a comment about the applicant accusing her

\footnotetext{
${ }^{26}$ Directive 95/46/EC of the European Parliament and of the Council of 24 October 1995 on the protection of individuals with regard to the precessing of personal data and on the free movement of such data. OJ L 281, 23.11.1995.

${ }^{27}$ Regulation (EU) 2016/679 of the European Parliament and of Council of 27 April 2016 on the protection of natural persons with regard to the processing of personal data and on the free movement of such data, and repealing Directive 95/46/EC. OJ L 119, 4.5.2016.

${ }^{28}$ Case C-18/18, Eva Glawishnig-Piesczek v. Facebook Ireland Limited, judgement of 3 October 2019.
} 
of a 'lousy traitor of the people', a 'corrupt oaf' and a member of a 'fascist party'. This post could be accessed by any Facebook user.

In July 2016, Ms. Piesczek wrote to Facebook, asking to delete the harmful comment. As Facebook did not comply with her request, Ms. Piesczek brought proceedings against it before the Austrian courts. The courts of first and second instance, basing their decisions on the national law, took the view that the public comment contained statements which were excessively harmful to the applicant's reputation and it was not permissible to rely on the right to freedom of expression for statements relating to politician if there was no connection with a political debate or a debate that was in the public interest. Therefore, she obtained an order prohibiting Facebook from publishing and/or disseminating the harmful comment and/or equivalent content.

The proceedings reached the Austrian Supreme Court, considering that the statements at issue were intended to damage the applicant's reputation, to insult her and to defame her, issued a preliminary ruling request on the interpretation of Directive 2000/31/EC on Electronic Commerce (the E-Commerce Directive ${ }^{29}$ to the CJEU.

Facebook Ireland provides the services of a host provider for the purposes of Article 14 of the E-Commerce Directive. Article 14/1 of this Directive is intended to exempt the host provider from liability where it satisfies one of the two conditions listed in that provision, that is to say, not having the knowledge of the illegal activity or information, or acting expeditiously to remove or to disable access to that information as soon as it becomes aware of it.

This exemption is without prejudice to the power of national courts to require the host provider concerned to terminate or prevent an infringement, including by removing the illegal information or by disabling access to it. On the other hand, national courts cannot subject host providers to a general monitoring obligations or impose a general obligation to seek facts or circumstances indicating illegal activity (Article 15/1) but such prohibition does not concern the monitoring obligations 'in a specific case' (Recital 47).

In this respect, the CJEU was asked to decide whether Article 15/1 of the E-Commerce Directive precluded national courts from requiring a host provider to remove content which is identical to content which was previously declared illegal, and any content with an equivalent meaning and if so, whether the national court could extend the injunction so that it had effect world-wide. In this case, AG Szpunar again gave his legal opinion ${ }^{30}$ as he had done in the Google v. CNIL Case.

As regards the 'identical content', AG Szpunar stated that in view of the ease with which information can be reproduced in the internet environment, the seeking and identification of information identical to that which has been characterised as illegal is necessary in order to ensure the effective protection of private life and personality rights (Opinion para.64). He added that such as obligation respects internet users' fundamental right to freedom of expression and information guaranteed in the Article 11 of the Charter of Fundamental Rights (Opinion para.65).

According to the Court since a social network facilitates the swift flow of information stored by the host provider between its different users, there is a genuine risk that information which was previously held to be illegal is subsequently reproduced and shared by another user of that network (Judgement para. 36). In those circumstances, in order to ensure that the host provider prevents any further infringement, it is legitimate for the court to be able to require that host provider to block access to the information stored, the content of which is 'identical' to the content previously declared to be illegal, or to remove that information, "irrespective of who requested the storage of that information". In view of the identical content of the information concerned, the injunction granted for that purpose cannot be regarded as imposing on the host provider an obligation to monitor generally the information which it stores, or a general obligation actively to seek facts or circumstances indicating illegal activity.

The 'equivalent content' is a more complicated issue than 'identical content'. According to AG Szpunar, the reference to information 'having equivalent content' is to information that scarcely diverges from the original information or to situations in which the message remains essentially unaltered (Opinion para.67). He took the view that unlike information identical to that characterised as illegal, information equivalent to that information cannot be identified unless a host provider employs sophisticated solutions (Opinion para 73). Implementation of those solutions would lead to censorship, so that freedom of expression and information might well be systematically restricted. However, in the context of such injunction, a host provider may be ordered to seek and identify the

\footnotetext{
${ }^{29}$ Directive 2000/31/EC of the European Parliament and of the Council of 8 June 2000 on certain legal aspects of information society services, in particular electronic commerce, in the Internal Market. OJ L 178, 17.7.2000.

${ }^{30}$ Opinion of Advocate General Szpunar in Case C-18/18, Eva Glawischnig-Piesczek v. Facebook Ireland Limited, delivered on 4 June 2019.
} 
Basar F.

Is freedom of expression in danger in the light of the CJEU decisions on the cases C-507-17 google v. CNIL ...

information equivalent to that characterised as illegal "only among the information disseminated by the user that disseminated the illegal information" not by the others (Opinion para.75).

In this respect, the CJEU stated that in using the words 'information with an equivalent meaning' the referring court intends to refer to "information conveying a message the content of which remains essentially unchanged and therefore diverges very little from the content which gave rise to the finding of illegality" (Judgement para 39). According to the Court, "the illegality of the content of information does not in itself stem from the use of certain terms combined in a certain way, but from the fact that the message conveyed by that content is held to be illegal, when, as in the present case, it concerns defamatory statements made against a specific person" (Judgement para.40). The Court added that equivalent information contains specific elements which are properly identified in the injunction, such as the name of the person concerned by the infringement, the circumstances in which that infringement was determined and equivalent content to that which was declared to be illegal. Differences in the wording of that equivalent content, compared with the content which was found to be illegal, must not, in any event, be such as to require the host provider to carry out an independent assessment of that content, since the host provider can apply automated search tools and techniques.

The most problematic part of the judgement may be the territorial scope of the jurisdiction. Having followed the Opinion of its AG Szpunar, the Court held that as is apparent from Article 18/1, the E-Commerce Directive does not make any provision in that regard for any limitation, including a territorial limitation, on the scope of the measures which Member States are entitled to adopt in accordance with the directive. Consequently, that Court decided that E-Commerce Directive does not preclude those injunction measures from producing effects worldwide (Judgement paras.49-50). However the Court added that in view of the global dimension of e-commerce, the EU legislature considered it necessary to ensure that EU rules in that area are consistent with the rules applicable at international level and it is up to Member States to ensure that the measures which they adopt and which produce effects worldwide take due account of those rules (Judgement paras 51-52).

\section{Concluding Remarks and Comments on Google and Facebook Cases}

The new types of transnational media companies such as Google and Facebook are enormously powerful actors and many parts of society today have become heavily dependent on them. They make it possible to consume and exchange huge amounts of information and knowledge through variety of services some of which offer great benefit and enjoyment. On the other hand, these companies collect vast amounts of data on their users that can be used for everything from advertising and consumer control to actual surveillance (Carlsson, 2016: 190). These companies are still growing by taking over other media companies or their businesses like You Tube, WhatsApp and Instagram ${ }^{31}$ and they exercise their power over their users by changing algorithms, terms and guidelines without transparency. Therefore, the CJEU's concern about personal rights and privacy is understandable to a certain extent.

First of all Google v. CNIL, exemplifies the strengthening of the European regulation of personal data under the GDPR (Tambou, 2019:82). In this case, the Court clarifies the requirements under which a request for de-referencing could be granted in cases where a link displayed on a search engine provides access to a webpage containing special categories of personal data. Actually, the GDPR has affirmed and expanded upon this right. Accordingly, the GDPR explicitly articulates a data subject's rights to have the data controller to erase personal data about him/her on several specific grounds. This would not apply, however, 'to the extent that processing is necessary to serve certain purposes, which include exercising the right of freedom of expression and receive information (Taylor, 2019:197). In this respect, data subject's rights - especially in respect of sensitive data- may override the public interest in freedom of information as a general rule, while allowing for exemptions considering specialties of the case and the public interest in receiving such information. While the CJEU's decision provided clarity on the scope of the right to be forgotten under EU law, it also leaves areas of uncertainty. This is because the Court recognises the competence of data protection authorities to determine the conditions which will justify de-referencing on all versions of a search engine (global application) based on national standards of the protection of fundamental rights. Therefore, it is expected that the CJEU will continue to receive more questions about global reach of the EU's data protection. In fact, G-P v. Facebook which was decided by the Court just a few days after this case provides a strong evidence for that.

$G-P$ v. Facebook Case is more problematic and will have more serious implications on the freedom of expression than Google v. CNIL Case. The issues that have caused the most controversy are how 'equivalent

\footnotetext{
${ }^{31}$ For example, Google acquired, on avarage, one company per week in 2010 and 2011 according to Evelyn M. Rusli’s article in New York Times dated 27 October 2011.
} 
information/content' is to be defined, the Court's perceived ignorance of the technology involved in content monitoring, and the Courts decision to open the door to injunctions relating to illegal online content issued by Member States' national courts having worldwide effect.

First, contrary to the Opinion of AG Szpunar, the judgement leaves the meaning of 'equivalent information' vague by not defining it in precise or foreseeable terms. Due to increasing pressure on technology and media companies from regulators, there are concerns that this may cause host providers to interpret 'equivalent content' broadly, thereby compromising freedom of expression (Silver and Pepper, 2019).

Secondly, it leaves it to national courts to precisely define the parameters of any 'equivalent content in the injunction, without considering that the relevant court may not fully appreciate the limitations of the filters even when the terms are precise. Relying on automated tools or filters alone to identify 'equivalent content' has been described as "highly erroneous" and "deeply flowed" (Daskal, 2019). As the Court emphasises that "illegality does not stem from the use of certain terms combined in a certain way" but "the message conveyed" (Judgement para.40), human assessment will be needed to interpret the conveyed message.

Thirdly, the principle of proportionality and balancing of fundamental rights is not clearly stated, although it may be implied in the Court's statement of "within a framework of relevant international law". Lastly, the Court did not mention the period during which such an injunction would be enforceable. As the time passes the public will probably lose interest and such injunctions may become disproportionate and have discouraging effect on freedom of expression (Knol-Radoja, 2020: 20). These problems in the judgement may lead to over broad removal of content, including legal content, ultimately infringing on freedom of expression.

Regarding the potential for global removal, the judgement means that a court in one Member State will be able "to order the removal of social media posts in other countries, even if they are not considered unlawful there" 32 . This would set a dangerous precedent where the courts of one country can control what internet users in another country can see and this could be open to abuse, particularly by regimes with poor human rights records. "Even in the present case, some of the content found to be illegal in Austria would likely have been found to be honest comment and hence not unlawful under the UK defamation law." ${ }^{33}$

Indeed, the limits of freedom of expression have not been discussed in either case, which I would like to raise especially with regard to G-P v. Facebook Case. Obviously, the legitimate aim of protecting the 'reputation and rights of others' is the most frequently used justification by national authorities to restrict freedom of expression and it is often invoked by politicians and civil servants (Bychawska-Siniarska, 2017: 63). However, the highest level of protection is granted to speech concerning politicians against a state, government and other state institutions ${ }^{34}$ In other words, much less protection would be granted to the privacy and reputation of politicians. In Von Hannover v. Germany, the ECtHR found that by being willing to work in the public sphere, politicians put themselves voluntarily into spotlight and thus need to tolerate more criticism and 'have a ticker skin'. ${ }^{35}$

In Lingen v. Austria ${ }^{36}$, the Court balanced freedom of the press against the right to reputation of high-level public official. In this case the ECtHR set out the principles that any internal law protecting by special or higher penalties politicians and all high-ranking officials in general against insult or defamation, in particular by the press, would be incompatible with Article 10 of ECHR. Where such provisions exist and are invoked by politicians, national courts must abstain from enforcing them. All these examples show us how difficult and complicated tasks the national courts are entrusted with and we will see the reactions of ECtHR to the new developments in data protection law in the near future.

\section{References}

1. Akdeniz, Y., Altiparmak, K. (2018). Turkey: Freedom of Expression in Jeopardy: Violations of the rights of authors, publishers and academics under the State of Emergency. Retrieved from https://www.englishpen. org/posts/campaigns/turkey-freedom-of-expression-in-jeopardy/ Last accessed: 07.09.2020.

2. Barendt. E. (2005), Freedom of Speech. Oxford University Press.

\footnotetext{
${ }^{32}$ Please see, https://www.article19.org/resources/cjeu-judgement-in-facebook-ireland-case-is-threat-to-online-free-speech/ Last accessed : 20.01.2020.

${ }^{33}$ Please see, https://inform.org/2019/11/09/territorial-scope-in-recent-cjeu-cases-google-v-cnil-glawishnig-piesczek-v-facebookcathryn-hopkins/ Last accessed: 25.01.2020.

${ }^{34}$ Human Rights Files No.18, Freedom of Expression in Europe, Case-law concerning Article 10 of the European Convention on Human Rights, Council of Europe, March 2017.

${ }^{35}$ Van Hannover v. Germany, 24 June 2004.

${ }^{36}$ Lingens v. Austria, No. 9815/82, 8 July 1986.
} 
3. Bresic, D. (2019). Google vs. CNIL: The CJEU determines the territorial scope of the right to de-referencing. Retrieved from https:/www.law.kuleuven.be/citip/blog/google-vs-cnil-the-cjeu-determines-the-territorialscope-of-the-right-to-de-referencing/ Last accessed: 15.01.2020.

4. Bychawska-Siniarska, D. (2017). Protecting the Right to Freedom of Expression under the European Convention on Human Rights. A handbook for legal practitioners, Council of Europe: 63-68.

5. Carlsson, U. (2016). Freedom of expression in the digital transition- Speech at the European Symposium on Media Policy 2015, Oslo 20 November 2015. Journal of Media Business Studies, 13/3: 187-197.

6. Daskal, J. (2019). A European Court Decision May Usher in Global. Retrieved from https: //slate.com/ technology/2019/10/european-court-justice-glawischnig-piesczek-facebook-censorship.htm. Last accessed: 20.01.2020.

7. Dunphy-Moriel, M., Ditted, A. (2019). Platforms told by CJEU: Do delete the derogatory remarks...If you're asked to. Retrieved from https://www.kemplittle.com/blog/platforms-cjeu-delete-the-derogatory-remarks/> Last accessed: 14.01.2020.

8. Frantziou, E. (2019). The Horizontal Effect of Fundamental Rights in the European Union-A Constitutional Analysis, Oxford Studies in European Law.

9. Human Rights Files No.18, Freedom of Expression in Europe, Case-law concerning Article 10 of the European Convention on Human Rights, Council of Europe, March 2017.

10. Knol-Radoja, K. (2020). Freedom of Expression on the Internet-Case 18/18 Eva Glawischnig-Piesczek v Facebook Ireland Limited. Balkan Social Science Review, 15, 7-24.

11. Lavranos, N. (2008). Towards a Solagne-Method Between International Courts and Tribunals' in Broude, T. and Shany, Y. (eds). The Shifting Allocation of Authority in International Law: Considering Sovereignty, Supremacy and Subsidiarity, Hart Publishing.

12. McGonagle, T. (2012). The Council of Europe against hate speech: Conundrums and challanges. Retrieved from https://rm.coe.int/16800c170f. Last accessed: 19.03.2020.

13. Samonte, M. (2019). Google v CNIL Case C-507/17: The Territorial Scope of the Right to be Forgotten under EU Law. Retrieved from https://europeanlawblog.eu/2019/10/29/google-v-cnil-case-c-507-17-the-territorialscope-of-the-right-to-be-forgotten-under-eu-law/ Last accessed: 20.01.2020.

14. Shapiro, T. (2019). CJEU Facebook judgement says member states can order platforms to remove defamatory material globally. Retrieved from https://www.wiggin.co.uk/insight/cjeu-facebook-judgment-says-memberstates-can-order-platforms-to-remove-defamatory-material-globally/ Last accessed: 15.01.2020.

15. Silver, I., Pepper, C. (2019). Monitoring online content: the impact of Eva Glawischnig-Piesczek v Facebook Ireland Limited. Retrieved from https:/www.reedsmith.com/en/perspectives/2019/11/monitoring-onlinecontent-the-impact-of-eva-glawischnig-piesczek-v-facebook. Last accessed: 20.01.2020.

16. Taylor, M. (2017). Google Spain Revisited: The Misunderstood Implementation of a Landmark Decision and How Public International Law Could Offer Guidance. European Data Protection Law Review (EDPL), 2 , pp.195-208.

17. Tambou, O. (2019). Lessons from the First Post-GDPR Fines of CNIL against Google LLC. European Data Protection Law Review (EDPL), 1, pp.80-84.

18. Topidi, K. (2019). Words That Hurt [1]: Normative and Institutional Considerations in the Regulation of Hate Speech in Europe. Retrieved from https://papers.ssrn.com/sol3/papers.cfm?abstract_id=3488707. Last accessed: 01.03.2020.

19. Tulkens, F. (2012). What to say is to do-Freedom of expression and hate speech in the case-law of the European Court of Human Rights' Euroepean Judicial Training Network. European Court of Human Rights. Retrieved from http://www.ejtn.eu/Documents/About\%20EJTN/INdependent\%20Seminars/TULKENS_ FRANCOISE_Presentation_When_to_Say_is_To_Do_Freedom_of_Expression_and_Hate_Speech_in_the_ Case_Law_of_the_ECtHR_October_2012.pdf $>$ Last accesed: 14.03.2020.

20. Wong, S., Murray, E. (2019). Retrieved from https://jolt.law.harvard.edu/digest/google-v-cnil-eu-rules-thatright-to-be-forgotten-does-not-apply-globally. Last accessed: 17.01.2020.

Стаття надійшла до редакції 20.05.2021. 